First Lady of Letters 
Early American Studies

Daniel K. Richter and Kathleen M. Brown, Series Editors

Exploring neglected aspects of our colonial, revolutionary, and early national history and culture, Early American Studies reinterprets familiar themes and events in fresh ways. Interdisciplinary in character, and with a special emphasis on the period from about 1600 to 1850 , the series is published in partnership with the McNeil Center for Early American Studies.

A complete list of books in the series is available from the publisher. 


\section{First Lady of Letters}

Judith Sargent Murray and the

Struggle for Female Independence

Sheila L. Skemp

\section{$\overline{\text { PENN }}$}

University of Pennsylvania Press

Philadelphia 
Copyright (C) 2009 University of Pennsylvania Press

All rights reserved. Except for brief quotations used for purposes of review or scholarly citation, none of this book may be reproduced in any form by any means without written permission from the publisher.

Published by

University of Pennsylvania Press

Philadelphia, Pennsylvania 19104-4112

Printed in the United States of America on acid-free paper

$\begin{array}{llllllllll}10 & 9 & 8 & 7 & 6 & 5 & 4 & 3 & 2 & 1\end{array}$

Library of Congress Cataloging-in-Publication Data

Skemp, Sheila $L$.

First lady of letters : Judith Sargent Murray and the struggle for female independence / Sheila L. Skemp.

p. cm. - (Early American Studies)

ISBN: 978-o-8122-4140-2 (alk. paper)

Includes bibliographical references and index.

1. Murray, Judith Sargent, 1751-1820. 2. Authors, American-18th century-Biography. 3. Authors, American-19th century-Biography. 4. Feminists-United States-Biography. 5. Feminism and literature-United States-History-18th century. 6. Feminism and literature-United States-History-19th century. 7. Women and literature-United States-History-18th century. 8. Women and literature-United States-History-19th century. I. Title.

PS808.M8 Z87 2009

$818^{\prime} .209-B 22$

2008035356 
To Murphy 
This page intentionally left blank 